\title{
Readiness for interaction with inoethnic subjects of education and ethnic worldview
}

\author{
Ravil A. Valiev ${ }^{\mathrm{a}}$, Tatiana V. Valieva ${ }^{\mathrm{b}}$, \\ Lyudmila A. Maksimova ${ }^{a}$, Valentina G. Karimova ${ }^{a}$ \\ a Social Psychology, Conflictology and Management chair, Ural State Pedagogical University, \\ Ekaterinburg, Russia \\ ${ }^{\mathrm{b}}$ Psychology chair, Ural Institute of Economics, Management and Law, Ekaterinburg, Russia \\ *Corresponding author. E-mail: rw1973@mail.ru
}

In the context of a significant increase of mass migration, the modern educational environment acquires the features of multiculturalism and teachers' readiness for interaction with inoethnic subjects of educational processes becomes a necessary condition for reduction of ethnic tensions and development of intercultural cooperation. Upon that, the formation of constructive intercultural relations requires the development of an ethnic worldview. In particular, readiness for interaction with inoethnic subjects of educational processes and the ethnic worldview are a precondition for the formation of real multiculturalism in interethnic relations. Objective of the research is to determine the intensity of the components of readiness for interaction with inoethnic subjects of educational processes and ethnic worldview components and to analyze their ratio concerning different subjects of educational processes. The problem of the correlation of readiness for interaction with inoethnic subjects of educational processes and ethnic worldview was solved through a survey of 113 pupils, students and future pupils' parents in the Sverdlovsk region. The exploratory factor analysis was applied to identify and describe the structural components of readiness under study structure and the structural components of the respondents' ethnic worldview; the degree of intensity of the mentioned components was analyzed by using the criterion $\chi^{2}$-Pearson. To identify the correlations between the components of readiness for interaction with inoethnic subjects in educational processes and ethnic worldview, the analysis by the criterion $r$-Pearson was conducted. The structural components of readiness for interaction with inoethnic subjects of educational processes among pupils, students and parents were empirically described; it is revealed that most of their correlations with the ethnic worldview components are inverse. Readiness for interaction with inoethnic subjects of educational processes is developed among the pupils in components such as empirical, communicative and cognitive; among the future teachers - in relational components; none of the components is expressed among the future pupils' parents. Multiethnic worldview is developed among the pupils in components such as ethnic 


\begin{abstract}
position and interethnic management. Among future teachers, the component of ethnic orientation is developed. Among the parents, it is the ability to go beyond the ethnic frame. The coordination of readiness for interaction with inoethnic subjects of educational processes with an ethnic worldview is of a multifaceted nature. The intensity of particular components of the readiness under study (behavioral, empirical, emotional, communicative and cognitive) is associated with a monoethnic worldview.
\end{abstract}

Keywords: readiness for interaction, the inoethnic subject, multicultural environment, educational process, ethnic worldview

\title{
Introduction
}

Currently, the separate existence of peoples and cultures is impossible due to the intensification of migration and demographic processes, the increase in number of ethnically mixed families and the formation of multinational groups in social institutions. In this regard, the issues of ethno-cultural natures become relevant, such as the prevention of ethnic conflicts, tolerance, issues of revival of a national culture and traditions and national characteristics in the process of training and education of the person (Arzamasceva, 2014). People face diversity in the multicultural environment and experience different systems of values, which often leads to misunderstanding and collisions, which in turn can escalate into conflicts. A significant decrease of the negative consequences caused by polyethnicity is feasible on the condition that a person acts as an active carrier of experience in the field of ethno-cultural and interethnic interaction and who is able to accept the peculiarities of specific ethnic groups to find adequate models of behavior to maintain a harmonious atmosphere and mutual trust to reach a high level of cooperation. The knowledge and skills of this kind are acquired not only and not as spontaneously as they are through specially organized activities. Accordingly, the problem of national contradictions and ethnic peculiarities begins to occupy the central place in the sphere of education.

The education system needs to provide consolidation and convergence of federal, regional and national multicultural curricula. In our opinion, multicultural education can be of service to this end (Gukalenko, 2014). A qualified teacher knowledgeable in questions of interaction with representatives of different ethnicities functions as a link in this process. Thanks to the purposeful work of a teacher in the field of ethnic interaction, other subjects' (parents and students) knowledge in the sphere, as well as their experience, skills and competencies, is actualized and developed.

Along with defining a child (and an adult) as "a person of a different nationality" ("of a different ethnic group") the term "inoethnic" is used. Inoethnic people are considered to be those who are perceived as strangers by teachers, pupils and their parents of the titular ethnicity. A synonym of this term is the word "non-Russian" that apparently also serves for designation of a stranger; for example, a child from the South of Russia can be called "non-Russian". On the other hand, a Tatar, for example, being formally a representative of another nation, is perceived by a teacher as "Russian" or "not strange". The term "not strange" in the context of this study refers to a student of the same nationality with the teacher - usually "Russian"; thus, "strange" refers to a child with a different nationality. 
Preparation of a teacher for interaction with representatives of a different ethnicity in the framework of traditional education at university is often dissipated in the process of professional pedagogical training, and the specificity of the organization of interaction with children of different nationalities is not emphasized or is considered to be of secondary importance. The future teacher bases interactions with other ethnic groups on his or her personal experiences, regardless of the education he receives. Readiness for interaction with inoethnic people is formed in the course of various disciplines, but these disciplines have no single approach to its formation of readiness for interaction with inoethnic people. As practice shows, the level of ethnocultural education depends on students' interest in the history of their own culture, opportunities to consider ethnic issues in the global context, on future teachers' motivation for development and improvement of their personal qualities and on the presence of conditions for self-development of each individual (Fedorova, 2008).

The professional standard of being a teacher clearly defines the mission, functions, competences and responsibilities of a specialist. The teacher's function of "educational activities" implies the formation of tolerance and behavioral skills in the changing multicultural environment (Federal pedagogical professional standard, 2013). The teacher should be aware of the historical diversity of cultures and civilizations, styles and forms of cultural and social life and the place of national culture in global historical-cultural process. The teacher should also become familiar with the role of ethnic and national factors in evolution of culture and civilization, know the peculiarities of multi-ethnic environment and be able to use the accumulated experience in development of individual creative abilities. Thereby, the issue arises concerning pedagogical university training aimed at preparation of specialists ready to interact with inoethnic subjects in the course of their work (for example, teaching the Russian language in classes with a large proportion of inoethnic children requires specific knowledge and skills) and whether these specialists are able to form and develop the corresponding readiness in other stakeholders in the educational process - pupils and parents.

The aggregate of these skills is called ethno-cultural competence, which assumes that the specialist possesses a volume of knowledge and skills that are not only essential for adaptation to the realities of a multicultural environment but are also sufficient to function in it actively (Poshtareva, 2006). Readiness for interaction with inoethnic subjects of educational processes is viewed by us as one of the indicators pointing to the development of the ethnocultural competence and appears as $a$ holistic integrative quality of a person characterized with a high level of knowledge in the field of social reality, positive emotionally axiological attitude to the characteristics of different cultures and the ability to interact with their particular representatives. This conception corresponds to the traditional point of view on the readiness to act, that emerged in the framework of psychology and pedagogy (Bondarevskaya \& Kul'nevich, 1999; Vasil'ev, 1978; D'yachenko \& Kandybovich, 1978; Rubinshtein 1957/2012; Strekalova, 2015; Uznadze, 1940/2004).

Fostering readiness for interaction with inoethnic subjects involves formation of an attitude of treating the polyethnicity as a global objective and positive reality; formation of a humanist attitude to representatives of different ethnic groups, their history and culture; formation of the system of values and ethical guidelines 
oriented on contacts with representatives of other ethnic groups; acquisition of knowledge of ethnic groups and interethnic relations; fostering respect for the sense of honor of other ethnic groups representatives; tolerance for different views and beliefs; tactful assessment of traditions, customs and rituals of different ethnic groups; development of skills and habits of ethnic interaction; and formation of skills and habits of overcoming the psychological barriers in communication, preventing situations that can cause emotional tensions in interethnic relations and avoiding conflicts (Belinskaya \& Stefanenko, 2000).

Readiness for interaction with representatives of a different ethnicity one way or another is connected with individuals' ethnic worldview. An ethnic worldview or ethnic consciousness conceptualizes the aggregate of all members' ideas of their own and other ethnic groups including social and psychological attitudes and stereotypes (Stefanenko, 1999/2014). The ethnic worldview demonstrates certain trends in attitudes to one's own and other ethnic groups. The following trends are identified: ethnic conformity, ethnorelativism, ethnocentrism and ethnic dominance.

Ethnocentrism is a strategy of considering norms and values of one's own group norms and values as a model when regarding which other cultures are assessed. Ethnorelativism is the realization that all cultures are equal but different. Ethnic dominance is a tendency to subordinate and suppress other cultures. Ethnic conformity means the readiness to submit to the majority, adopting the norms of other cultures (Stefanenko, 2014).

An empirical study involving pupils, students and future pupils' parents was conducted. The objective of the study was to determine the intensity of the components of readiness for interaction with inoethnic subjects of educational processes and the components of their ethnic worldview as well as to identify and describe the ratio of the mentioned components concerning different subjects of educational process. The hypothesis of the study was based on the assumptions that 1) readiness for interaction with inoethnic subjects of educational process is not formed spontaneously, for its significant prevalence at a high level of development among different subjects of educational process as specially organized conditions for its formation are required; correspondingly, no significant prevalence will be observed if specially organized formation is not provided, and 2) in comparatively mono-ethnic conditions of the region (for example, the northern part of the Sverdlovsk region, where more than $90 \%$ of the population is ethnic Russians), formation of a multi-ethnic worldview among different subjects of educational processes is impeded, which is expressed through their ethnic stereotyping, the aspiration to dominate and tendency to ethnocentrism and a poor representation of other ethnic groups in their ethnic worldview.

\section{Method}

The research was conducted in the Sverdlovsk region among 11th grade students, preschoolers' parents and students enrolled in higher education. The research sample included $3011^{\text {th }}$ grade students, 23 senior preschoolers' parents and 60 students of teacher training in higher education institutions. The total sample size was 113 participants. 
The diagnostics of readiness for interaction with inoethnic subjects in educational processes was held through multiple methods, including the following:

1. A proprietary questionnaire, "Readiness for interaction with inoethnic subjects of the educational process", which was aimed at studying particular components of such readiness (Valiev \& Karimova, 2014). The questionnaire includes 12 questions designed to explore a) the respondents' awareness of the ethnic groups residing on the territory of the Sverdlovsk region; b) the importance of preparation for interaction with inoethnic subjects in educational process and the respondents' self-assessment of such a readiness; c) the respondents' experience of such an interaction and feelings arising in this process; and d) the strategies selected by the respondents to cope with interethnic conflicts in the process of interaction (multiculturalism, assimilation or adaptation).

2. The Bogardus Social Distance Scale (as cited in Pochebut, 2007), designed to measure social distance in contacts with other ethnic groups.

3. A Diagnostic test by G. U. Soldatova, which is designed to measure the characteristics of ethnic stereotypes (Soldatova, 1998). The methodic is designed on the basis of the semantic differential method and allows one to assess the emotional-evaluative component of a social stereotype. The stimulus material is a set of 20 pairs of qualities, with poles that differ in connotative (affective) parameters and with semantic meanings that are regarded as similar (for example, the positive pole has the quality "courageous", and the negative one has the quality "reckless"). The objects of evaluation are the respondent; the "ideal", a typical representative of the ethnic group the respondent belongs to; and the typical representatives of other ethnic groups involved in the process of interethnic relations. The respondent is to assess a card where four pairs of properties are arranged according to their connotative parameters. In total, there are five cards with eight qualities on each card. When processing the results, the researcher receives the data concerning the orientation of an ethnic stereotype positive or negative, the emotional certainty/uncertainty and intensity. It is also possible to analyze the information concerning ethnicity and the respondents' self-esteem and ethnic preferences.

4. The values spectrum method by D. A. Leont'ev shows the degree of value of the objects under study. Two types of school environments, monoethnic and polyethnic, were chosen as the objects (Leont'ev, 1999/2007). The method belongs to the category of repertory grids, with the ultimate human needs by Maslow serving as the specified constructs. The respondent is asked to select from a list the ones that, in his or her opinion, are inherent to the object under assessment. The researcher is able to determine the degree of value of the studied objects and their value ranges.

5. A narrative method, allowing to identify the peculiarities of the respondents' representation of their experiences gained while interacting with inoethnic subjects of educational processes (Kalmykova \& Mergentaler, 1998). The respondent is asked to tell a story about some significant event in his/her life. 
In the present study, the respondents told a story about a particular important event in their lives when they interacted in educational processes with children and parents belonging to other ethnic groups. The following processing of the narratives is based on the qualitative analysis of the experience representations manifesting in the story. In the present study, the following parameters for the analysis were developed: 1) types of attitude to inoethnic subjects (negative, neutral or positive); 2) types of the subjects' interaction in the course of history according to the classification by $\mathrm{K}$. Thomas - cooperation, competition, adaptation, avoidance or compromise (as cited in Grishina, 2000/2008); 3) the inoethnic subject's nationality in the course of history; 4 ) the modality of events representation by M. N. Epstein (Jepshtejn, 2001) - the conveyed attitude to the event and actions towards it: existential (contingent, possible, necessary or impossible); cognitive (doubt, supposition or certainty); potential (capacity or need); and 5) the position concerning the event - active (transformation of the circumstances), passive (submission to the circumstances) or contemplative (description of the current circumstances.

To reveal the peculiarities of the education process subjects' ethnic worldview a modified projective test by S. D. Gurieva was applied (Gurieva \& Kinunen, 2007; Valiev, Valieva, Vorob'eva, \& Smirnov, 2014). This method is aimed at identifying unconscious tendencies of attitudes towards one's own and other ethnic groups. According to the original method, the respondent is asked "to settle" any eight nationalities, including the one the respondent identifies himself/herself with, within a circle drawn in the form. Modification of the method consisted in the fact that the respondents were offered a blank A4 sheet of paper where they themselves drew the circle. This modification enabled us to introduce additional indicators for the data analysis. The following indicators are proposed: the breadth of ethnic worldview representation of various ethnic groups and 2) ethnic tendencies - the predisposition to think, behave and act towards this or that ethnic group in a certain way. We introduced three additional indicators: 1 ) ethnic space size - the size of the drawn planet, 2) ethnic orientation - the part of the world to which a greater number of nationalities noted by the respondent belongs (Russia, CIS and World) and 3) ethnic worldview configuration - mutual position, proportion of the ethnic groups in the mind. Four types of the configuration were empirically identified - diffusive (disordered arrangement of the ethnic groups without any borders), radial (radial borders proceed from the center of the "planet", dividing it in different proportions), vertical (the ethnic groups are located top-bottom with the delineation of boundaries between them) and nuclear (the "core" - circle-shaped boundaries of an ethnic group in the center of "the planet" with radial borders of other ethnic groups proceeding from it).

The obtained results were subjected to the exploratory factor analysis (EFA) procedure according to the Principal components method with Varimax rotation in the computer program STATISTICA 6.0. As a result, an eight-factor structure of readiness for interaction with inoethnic subjects of educational processes and a five-factor structure of the educational process subjects' ethnic worldview were obtained. 


\section{Results}

The obtained factor structure of readiness for interaction with inoethnic subjects covers $52 \%$ of the total variance and includes 43 of the initial 96 variables. The first and second factors of this structure combine the values attributed by the respondents to MonoCSE and MultiCSE (Figure 1).

The first factor includes the indicators of MonoCSE value - the positive pole and the value of MultiCSE integrity - the negative pole. Thus, one pole demonstrates the importance of ethnic homogeneity of the school environment and the other demonstrates the value of unity of the heterogeneous school environment in its diversity. This allows us to name the first factor as "ethnic homogeneity/diversity of school environment value". The second factor is unambiguously interpreted as "multi- or mono-ethnic school environment authenticity value" because the corresponding values are situated at the poles of this factor. The third factor on the negative pole contains the variables pointing to the imposed accepting attitude to inoethnic subjects of the educational process, which is the attitude of forced adaptation. At the positive pole are the variables that can be attributed to personal attitudes because they contain doubt, uncertainty and the value of the school environment. This allows us to entitle this factor as "personal or imposed attitude to school environment". The fourth factor includes positions associated with the activity or passivity in interaction with inoethnic subjects of educational processes with their assimilation or adaptation; therefore, this factor can be interpreted as "managing or leveling ethnic differences in school environment" because assimilation and adaptation are the corresponding ways to address ethnic differences. The fifth factor can be entitled "presence or absence of experience in interaction with inoethnic subjects in school environment" as these types of variables are displayed on the poles of the factor in question. Variables at the poles of the sixth factor allow us to name it as "positive or negative attitude towards interaction with inoethnic subjects in school environment". The seventh factor is interpreted as "the closedness-openness in communication with inoethnic subjects in school environment" as multiculturalism implies acknowledgement, acceptance and actualization of the open position in communication on the part of interacting ethnic groups and adaptation; adaptation implies the closed position to a large extent as adaptation is a forced interaction.

The eighth factor is related to the perceptions of differences inherent to ethnic groups and their differentiation. The contemplative position in interaction with inoethnic subjects is the position of research and observation of ethnic differences implying no eagerness to change the differences or impose some manner of behavior on other ethnic group. This seems to be the reason for co-occurrence of this variable with the value indicator of the uniqueness of polyethnic school environment at one of the factor poles. Attribution of the value of uniqueness to the mono-ethnic environment at the opposite pole also reflects differentiation of this environment from others. This factor is entitled "differentiation of the mono- or multiethnic school environment". Thus, comparing the content of each factor with the structural components of psychological readiness, the following factors were identified (in order): axiological (first and second factors), relational, behavioral, experimental, emotional, communicative and cognitive. 
To identify the correlation of the components of readiness for interaction with inoethnic subjects of educational processes with the peculiarities of the respondents' ethnic worldview, the data were obtained on the basis of the modified methodology "Create a planet" by S. D. Gurieva and was subjected to exploratory factor analysis (EFA). The factor structure of the ethnic worldview of educational processes subjects accounts for $50 \%$ of the total variance and includes 23 of the initial 35 variables (Figure 2). The obtained factors' content can be interpreted in the same way as it was done in the previous study (Valiev et al., 2014).

The first factor "Ethnic orientation" determines the orientation of a subject towards a closed (the positive pole) or open (the negative pole) ethnic culture. The second factor "Ethnic distance" includes ethnic groups from distant or an immediate ethnic space. The third factor "Ethnic frame - organization of inter-ethnic perception" describes the inability (the positive pole - ethnocentrism) or ability (the negative pole - ethnorelativism) to go beyond the frame of experiences of perception and cognition of other ethnic groups. The fourth factor "Ethnic position" is associated with the peculiarities of ethnic authority and is the model for ethnic development (the positive pole) or ethnic oppression-dominance (the negative pole). The fifth factor "Inter-ethnic management" shows the characteristics of the unipolar or multipolar (diffusive configuration and a large size of the world at the negative pole) ethnic worldview organization.

Table 1. Factor poles verifying the level of development of components

\begin{tabular}{llc}
\hline \multicolumn{1}{c}{ Content of the pole } & Negative \\
& \multicolumn{2}{c}{ Readiness for interaction with inoethnic subjects of educational processes } \\
\hline 1 & School environment ethnic diversity value & Positive \\
2 & School environment authenticity value & Positive \\
3 & Personal attitude to school environment & Negative \\
4 & Managing ethnic differences in school environment & Positive \\
5 & Experience of interaction with inoethnic subjects in school environment & Positive \\
6 & Positive attitude to interaction with inoethnic subjects in school environment & Negative \\
7 & Openness of communication with inoethnic subjects in school environment & Negative \\
8 & Differentiation of the multiethnic school environment & \\
\hline & &
\end{tabular}

Subjects' of education ethnic worldview

1 Orientation towards open ethnic culture

Negative

2 Presence of immediate ethnicities in worldview

Negative

3 Ethnorelativism

Negative

4 Ethnic authority/ model of development

Positive

5 Multipolar organization of worldview

Negative 


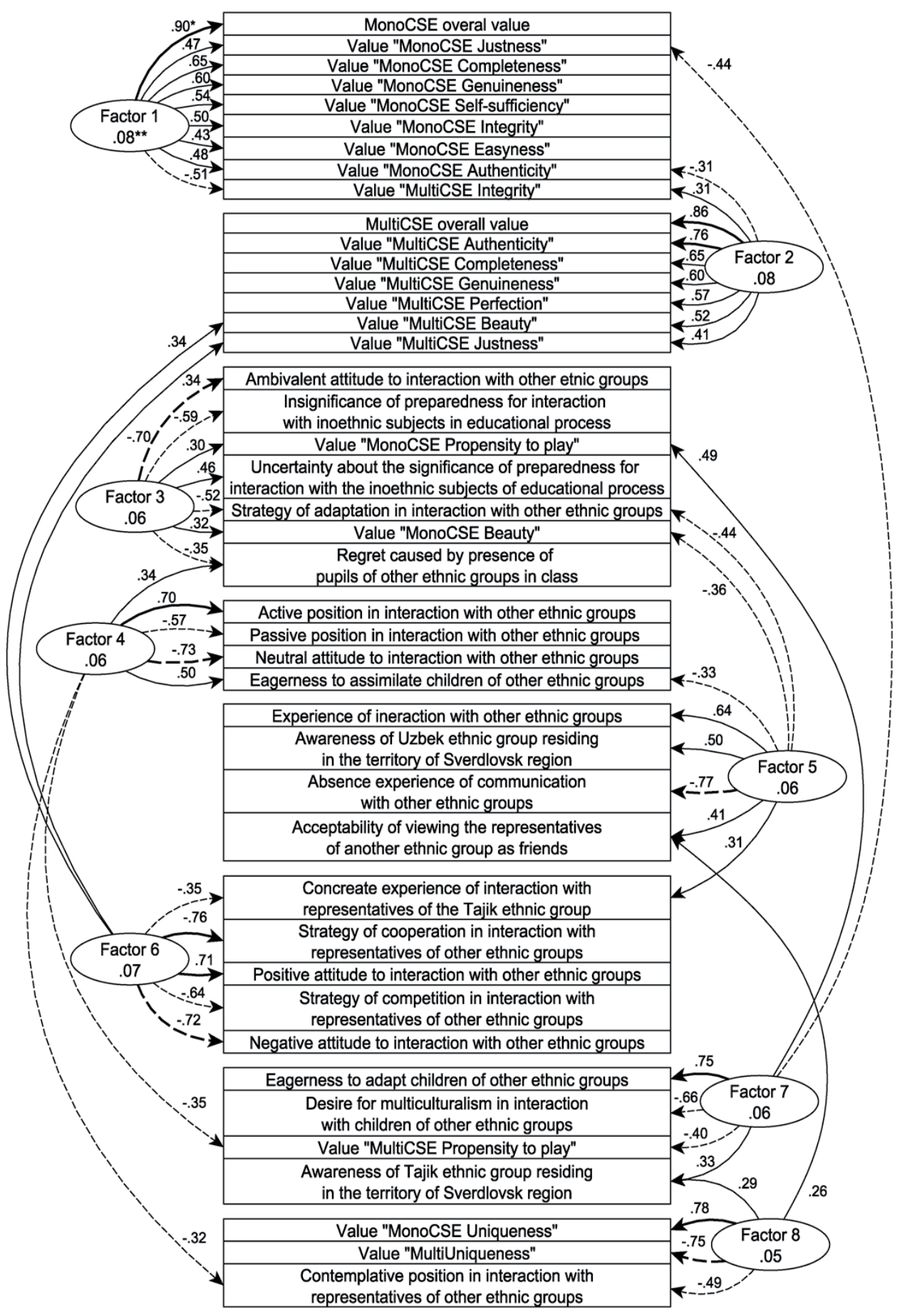

Figure 1. Factor structure of ethnic worldview of subjects of educational space (the solid line - the positive pole of the factor, the dotted line - the negative pole of the factor; the prominent arrows - the prevailing factor loadings). ${ }^{\star}$ Factor loading. ${ }^{\star \star}$ The fraction of variance caused by the factor. 


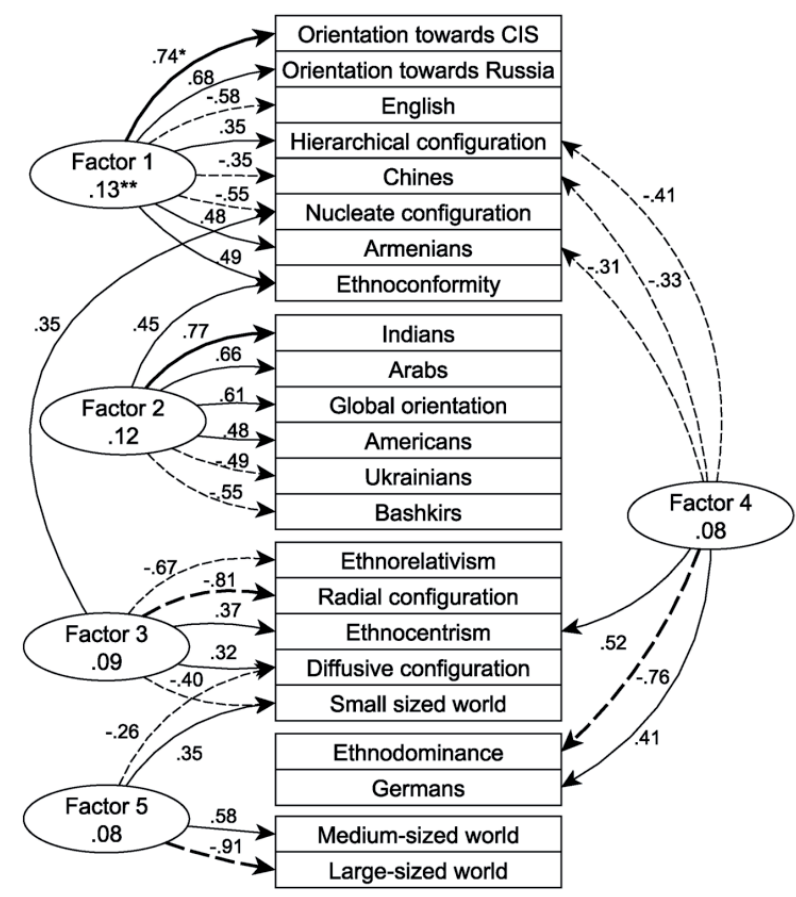

Figure 2. Factor structure of ethnic worldview of subjects of educational space (the solid line - the positive pole of the factor, the dotted line - the negative pole of the factor; the prominent arrows - the prevailing factor loadings). ${ }^{*}$ Factor loading. ${ }^{* *}$ The amount of variance accounted for by the factor.

In the first stage, before conducting the subsequent analysis of the data, the pole factors in both factor structures verifying the substantial development of this component were selected (Table 1). Accordingly, the signs of individual factor assessments were changed to reflect the level of development of components of readiness for interaction with inoethnic subjects and the ethnic worldview. Thus, the high level of readiness for interaction with inoethnic subjects in the process of education is shown by such indicators as school environment, ethnic diversity value, school environment authenticity value, personal attitude to the school environment, managing ethnic differences in the school environment, experience of interaction with inoethnic subjects in the school environment, positive attitude to interaction with inoethnic subjects in the school environment, openness of communication with inoethnic subjects in the school environment and differentiation of the multiethnic school environment. The highly developed ethnic worldview, i.e., the multiethnic one, is demonstrated through such indicators as orientation towards an open ethnic culture, the presence of immediate ethnicities in one's worldview, ethnorelativism, the ethnic authority/model of development and a multipolar organization of worldview.

Using the transformed individual factor assessments, common trends of representation of the factor-component poles of readiness for interaction with inoethnic 
subjects of educational processes and the respondents' ethnic world view were revealed. Basing on the nature of the factor evaluation, each respondent was assigned to a certain pole of the factor that was denoted through a dichotomous scale. Some respondents were not included in the analysis because their factor evaluation coincided with the average for the factor, i.e., it was equal to zero, and could not be attributed to one or the other pole of the factor. The significance of the deviation of the obtained distribution from the uniform distribution was analyzed for each factor; the criterion $\chi^{2}$-Pearson was applied (Tables 2-3).

Table 2. Representation of structure of readiness for interaction with inoethnic subjects of educational processes

\begin{tabular}{|c|c|c|c|c|c|c|c|}
\hline \multirow{2}{*}{ № } & \multirow{2}{*}{ Factor poles content } & \multicolumn{2}{|c|}{ Students } & \multicolumn{2}{|c|}{$\begin{array}{c}\text { Future } \\
\text { teachers }\end{array}$} & \multicolumn{2}{|c|}{ Parents } \\
\hline & & $f$ & $\chi^{2}$ & $f$ & $x^{2}$ & $f$ & $\chi^{2}$ \\
\hline \multirow[b]{2}{*}{1} & $\mathrm{SE}^{\star}$ ethnic diversity value & 10 & \multirow{2}{*}{$\begin{array}{c}0.182 \\
\mathrm{p}=0.670\end{array}$} & 26 & \multirow{2}{*}{$\begin{array}{c}0.831 \\
\mathrm{p}=0.362\end{array}$} & 18 & \multirow{2}{*}{$\begin{array}{c}1.200 \\
\mathrm{p}=0.273\end{array}$} \\
\hline & SE ethnic homogeneity value & 12 & & 33 & & 12 & \\
\hline \multirow{2}{*}{2} & Multiethnic SE authenticity value & 3 & \multirow{2}{*}{$\begin{array}{c}12.565 \\
p=0.000\end{array}$} & 34 & \multirow{2}{*}{$\begin{array}{c}1.067 \\
\mathrm{p}=0.302\end{array}$} & 11 & \multirow{2}{*}{$\begin{array}{c}2.133 \\
\mathrm{p}=0.144\end{array}$} \\
\hline & Monoethnic SE authenticity value & 20 & & 26 & & 19 & \\
\hline \multirow{2}{*}{3} & Personal attitude to multiethnic SE & 11 & \multirow{2}{*}{$\begin{array}{c}0.043 \\
p=0.835\end{array}$} & 40 & \multirow{2}{*}{$\begin{array}{c}6.667 \\
p=0.010\end{array}$} & 12 & \multirow{2}{*}{$\begin{array}{c}0.862 \\
\mathrm{p}=0.353\end{array}$} \\
\hline & Imposed attitude to multiethnic SE & 12 & & 20 & & 17 & \\
\hline \multirow{2}{*}{4} & Managing ethnic differences in SE & 13 & \multirow{2}{*}{$\begin{array}{c}0.391 \\
p=0.532\end{array}$} & 35 & \multirow{2}{*}{$\begin{array}{c}1.667 \\
p=0.197\end{array}$} & 6 & \multirow{2}{*}{$\begin{array}{c}10.800 \\
p=0.001\end{array}$} \\
\hline & Leveling ethnic differences in SE & 10 & & 25 & & 24 & \\
\hline \multirow{2}{*}{5} & $\begin{array}{l}\text { Experience of interaction with } \\
\text { inoethnic subjects in SE }\end{array}$ & 22 & \multirow{2}{*}{$\begin{array}{c}19.174 \\
p=0.000\end{array}$} & 31 & \multirow{2}{*}{$\begin{array}{c}0.067 \\
p=0.796\end{array}$} & 8 & \multirow{2}{*}{$\begin{array}{c}6.533 \\
p=0.011\end{array}$} \\
\hline & $\begin{array}{l}\text { Absence of experience of interac- } \\
\text { tion with inoethnic subjects in SE }\end{array}$ & 1 & & 29 & & 22 & \\
\hline \multirow[b]{2}{*}{6} & $\begin{array}{l}\text { Positive attitude to interaction with } \\
\text { inoethnic subjects in SE }\end{array}$ & 12 & \multirow{2}{*}{$\begin{array}{c}0.043 \\
\mathrm{p}=0.835\end{array}$} & 35 & \multirow{2}{*}{$\begin{array}{c}1.667 \\
p=0.197\end{array}$} & 17 & \multirow{2}{*}{$\begin{array}{c}0.533 \\
\mathrm{p}=0.465\end{array}$} \\
\hline & $\begin{array}{l}\text { Negative attitude to interaction } \\
\text { with inoethnic subjects in SE }\end{array}$ & 11 & & 25 & & 13 & \\
\hline \multirow[b]{2}{*}{7} & $\begin{array}{l}\text { Openness of communication with } \\
\text { inoethnic subjects in school envi- } \\
\text { ronment }\end{array}$ & 18 & \multirow{2}{*}{$\begin{array}{c}7.348 \\
p=0.007\end{array}$} & 28 & \multirow{2}{*}{$\begin{array}{c}0.267 \\
p=0.606\end{array}$} & 13 & \multirow{2}{*}{$\begin{array}{c}0.533 \\
\mathrm{p}=0.465\end{array}$} \\
\hline & $\begin{array}{l}\text { Closedness of communication } \\
\text { with inoethnic subjects in school } \\
\text { environment }\end{array}$ & 5 & & 32 & & 17 & \\
\hline \multirow[b]{2}{*}{8} & $\begin{array}{l}\text { Differentiation of the monoethnic } \\
\text { school environment }\end{array}$ & 18 & \multirow{2}{*}{$\begin{array}{c}7.348 \\
p=0.007\end{array}$} & 25 & \multirow{2}{*}{$\begin{array}{c}1.667 \\
p=0.197\end{array}$} & 13 & \\
\hline & $\begin{array}{l}\text { Differentiation of the multiethnic } \\
\text { school environment }\end{array}$ & 5 & & 35 & & 15 & $\mathrm{p}=0.705$ \\
\hline
\end{tabular}

* SE - school environment. 
Table 3. Representation of structure of maturity of respondents' ethnic worldview

\begin{tabular}{|c|c|c|c|c|c|c|c|}
\hline \multirow[t]{2}{*}{ № } & \multirow[t]{2}{*}{ Factor poles content } & \multicolumn{2}{|c|}{ Students } & \multicolumn{2}{|c|}{$\begin{array}{l}\text { Future } \\
\text { teachers }\end{array}$} & \multicolumn{2}{|c|}{ Parents } \\
\hline & & $f$ & $x^{2}$ & $f$ & $x^{2}$ & $f$ & $x^{2}$ \\
\hline \multirow[b]{2}{*}{1} & Orientation towards open ethnic culture & 1 & \multirow{2}{*}{$\begin{array}{c}19.174 \\
p=0.000\end{array}$} & 44 & \multirow{2}{*}{$\begin{array}{c}13.067 \\
p=0.000\end{array}$} & 19 & \multirow{2}{*}{$\begin{array}{c}2.133 \\
\mathrm{p}=0.144\end{array}$} \\
\hline & Orientation towards closed ethnic culture & 22 & & 16 & & 11 & \\
\hline \multirow{2}{*}{2} & Presence of immediate ethnicities in worldview & 7 & \multirow{2}{*}{$\begin{array}{c}2.909 \\
p=0.088\end{array}$} & 36 & \multirow{2}{*}{$\begin{array}{c}2.400 \\
p=0.121\end{array}$} & 18 & \multirow{2}{*}{$\begin{array}{c}1.200 \\
p=0.273\end{array}$} \\
\hline & Presence of distant ethnicities in worldview & 15 & & 24 & & 12 & \\
\hline \multirow{2}{*}{3} & Ethnorelativism & 8 & \multirow{2}{*}{$\begin{array}{c}2.130 \\
\mathrm{p}=0.144\end{array}$} & 19 & \multirow{2}{*}{$\begin{array}{c}8.067 \\
p=0.005\end{array}$} & 20 & \multirow{2}{*}{$\begin{array}{c}3.333 \\
\mathrm{p}=\mathbf{0 . 0 6 8}\end{array}$} \\
\hline & Ethnocentrism & 15 & & 41 & & 10 & \\
\hline \multirow{2}{*}{4} & Ethnic model of development & 16 & \multirow{2}{*}{$\begin{array}{c}3.522 \\
p=0.061\end{array}$} & 26 & \multirow{2}{*}{$\begin{array}{c}1.067 \\
p=0.302\end{array}$} & 17 & \multirow{2}{*}{$\begin{array}{c}0.533 \\
p=0.465\end{array}$} \\
\hline & Ethnic dominance & 7 & & 34 & & 13 & \\
\hline \multirow[b]{2}{*}{5} & Multipolar world organization & 16 & \multirow{2}{*}{$\begin{array}{c}3.522 \\
p=0.061\end{array}$} & 36 & \multirow{2}{*}{$\begin{array}{c}2.400 \\
p=0.121\end{array}$} & 19 & \multirow{2}{*}{$\begin{array}{c}2.133 \\
\mathrm{p}=0.144\end{array}$} \\
\hline & Unipolar world organization & 7 & & 24 & & 11 & \\
\hline
\end{tabular}

To consider the nature of the correlation between the studied readiness and ethnic worldview, the respondents' individual factor scores were subjected to the correlation analysis by $r$-Pearson criterion. Firstly, a correlation analysis was applied to the whole sample independently of the respondents' experience of participation in educational process (Table 4). Secondly, the correlations were computed for each group separately (Table 5). Both of the tables show significant correlations only.

Table 4. Correlations of readiness for interaction with inoethnic subjects with ethnic worldview on the whole sampling $(\mathrm{n}=113)$

\begin{tabular}{|c|c|c|c|c|c|c|}
\hline \multirow{2}{*}{$\begin{array}{c}\text { Ethnic } \\
\text { Worldview } \\
\text { components }\end{array}$} & \multicolumn{6}{|c|}{ Components of readiness for interaction with inoethnic subjects } \\
\hline & $\begin{array}{l}\text { Axiolo- } \\
\text { gical }^{\star \star}\end{array}$ & Behavioral & $\begin{array}{l}\text { Experi- } \\
\text { mental }\end{array}$ & Emotional & $\begin{array}{l}\text { Commu- } \\
\text { nicative }\end{array}$ & Cognitive \\
\hline Ethnic orientation & $0.22^{*}$ & & -0.27 & & -0.26 & $-0.23^{*}$ \\
\hline Ethnic distance & & & -0.28 & & & \\
\hline Ethnic frame & & $-0.23^{*}$ & & & & \\
\hline Ethnic position & & & & & $0.20^{*}$ & \\
\hline $\begin{array}{l}\text { Inter-ethnic } \\
\text { management }\end{array}$ & & & & -0.17 & & \\
\hline
\end{tabular}

${ }^{\star} \mathrm{p} \leq 0.05 .{ }^{* *}$ Multiethnic school environment authenticity value. 
Table 5. Correlations of readiness for interaction with inoethnic subjects with ethnic worldview in groups

\begin{tabular}{|c|c|c|c|c|c|c|}
\hline \multirow{2}{*}{$\begin{array}{c}\text { Ethnic } \\
\text { worldview } \\
\text { components }\end{array}$} & \multirow{2}{*}{ Groups } & \multicolumn{5}{|c|}{$\begin{array}{l}\text { Components of readiness for interaction } \\
\text { with inoethnic subjects }\end{array}$} \\
\hline & & $\begin{array}{l}\text { Axiolo- } \\
\text { gical }^{* *}\end{array}$ & $\begin{array}{l}\text { Axiolo- } \\
\text { gical }^{* * *}\end{array}$ & $\begin{array}{l}\text { Experi- } \\
\text { mental }\end{array}$ & Emotional & $\begin{array}{l}\text { Commu- } \\
\text { nicative }\end{array}$ \\
\hline $\begin{array}{l}\text { Ethnic } \\
\text { orientation }\end{array}$ & Students & $-0.46^{\star}$ & & & & \\
\hline Ethnic & Future teachers & & & & $-0.25^{*}$ & \\
\hline distance & Parents & $0.40^{*}$ & & $-0.41^{\star}$ & & -0.47 \\
\hline Ethnic & Future teachers & & & -0.37 & & \\
\hline frame & Parents & & 0.50 & & & \\
\hline $\begin{array}{l}\text { Ethnic } \\
\text { position }\end{array}$ & Students & & & & & $0.47^{\star}$ \\
\hline $\begin{array}{l}\text { Inter-ethnic } \\
\text { management }\end{array}$ & Parents & & & & & $0.45^{\star}$ \\
\hline
\end{tabular}

${ }^{*} \mathrm{p} \leq 0.05 .{ }^{* *}$ School environment ethnic diversity value. ${ }^{* *}$ Multiethnic school environment authenticity value.

\section{Discussion}

Tables 2 and 3 show that the following pole components of readiness for interaction with inoethnic subjects in educational processes are significantly presented in the group of students: the value of multi-ethnic SE authenticity, the value of experience of interaction with inoethnic subjects in SE, the value of opened communication with inoethnic subjects in SE and the value of differentiation of the multi-ethnic SE. The tendency of orientation towards the closed ethnic culture, i.e., adhering to the cultural identity in interaction with other ethnic groups, prevails in their worldview. The long ethnic distance, ethnocentrism and multipolar worldview are also presented at the level of tendency.

Thus, three of eight components of readiness for interaction with inoethnic subjects of educational processes are most distinct in the group of students: experimental, communicative and cognitive. This supports the fact that the multiethnic school environment is not clearly valued by high-school students; the ambivalence of components, such as emotional, relational and axiological (overall value of SE), is represented among them; however, no locus of the behavioral component is represented. The component "school environment authenticity value" in the studied sample is more often represented at a low level. The orientation towards the closedness of ethnic culture in the students' ethnic worldview is of use in the explanation of the students' attitude to a multiethnic school environment that implies rather a formal contact with other ethnic groups with no active personal involvement.

In the future teachers' group, personal attitudes to multiethnic school environments is significantly represented, and their ethnic worldview is characterized with an orientation towards an open ethnic culture and ethnocentrism. This shows that 
future teachers are open to other ethnic groups and perceive them through the prism of their own ethnic norms and rules.

In the parents' group, leveling of ethnic differences in the school environment and a lack of experience of interactions with inoethnic subjects in educational processes are represented. In the parents' worldview ethnorelativism statistically prevails. The absence of experience of interactions with inoethnic subjects among the parents can be explained by the fact that during the respondents' school years the amount of inoethnic subjects in educational institutions was significantly smaller. The pursuit of adaptation of representatives of other ethnic groups (i.e., to change them according to models, norms and rules of one's own culture), and, at the same time, the realization of the equality of all ethnic groups could suggest that relativism is actualized among the parents in the circumstances of distant contacts and in the pursuit of adaptation (in the circumstances of a close contact). On the basis of the whole sample we can say that different subjects of educational processes present different trends in the prevalence of this or that component of both readiness for interaction with inoethnic representatives and ethnic worldview. The obtained results indicate that the hypothesis was confirmed: in the studied sample, developed readiness for interaction with inoethnic subjects in educational processes does not occur more often than an undeveloped one, and the prevalence of a multiethnic worldview over a monoethnic worldview was not revealed either.

The analysis of correlations obtained for the whole sample (Table 4) shows that seven of the five correlations are inverse correlations. In general, the connection of an ethnic worldview with a readiness for interaction with inoethnic subjects in educational processes in the sample under consideration is not close as all of the obtained correlations in their absolute values are below 0.30 . The analysis of correlations in each respondent's groups (Table 5) showed stronger, moderate or medium correlations. The value of the diversity of the school environment diversity among parents is correlated with ethnic distance in interaction (0.40) and with the ethnic orientation toward the closedness of ethnic culture among students $(-0.46)$. The multiethnic school environment authenticity value is directly correlated with the parents' abilities to go beyond their own ethnic group experiences in perception and cognition of other ethnicities (0.50). The absence of experience of interactions with inoethnic subjects in educational processes among the parents is interconnected with their long ethnic distance (-0.41), and, among future teachers, it is interconnected with the ethnic frame $(-0.37)$. A positive attitude toward other ethnic groups among future teachers is connected with their long ethnic distance (-0.25). Parents' multiculturalism in interactions with other ethnicities is correlated with their long ethnic distance (-0.47) and the multipolarity of the ethnic worldview organization (0.45), and, among students, it is correlated with perceiving their own ethnicity as a model for other ethnic groups' development (0.47). On the whole, the correlations defined in the course of the study demonstrate complexity and variety of the correlation between readiness for interaction with inoethnic subjects in educational processes and a person's ethnic worldview. The large number of inverse correlations both in the whole sample and in each group separately suggests that ethnic worldview and readiness for interaction with inoethnic subjects 
in educational processes are correlated on in terms of compensation. More to the point, it should be noted that a correlation between ethnic worldview and the relational component of readiness in this study was represented neither in the whole sample nor in any of the groups. This, from our point of view, is explained by the fact that a given component, as a manifestation of a person's semantic sphere, belongs to a deeper level of the psychic processes than worldview and could be only connected with the latter through other psychic processes, such as emotional or cognitive ones.

\section{Conclusion}

The study results allow us to make the following basic conclusions.

Readiness for interaction with inoethnic subjects in educational processes is represented in the following components: axiological, relational, behavioral, experimental, emotional, communicative and cognitive. The distinctness of these components is represented in different ways with different subjects of educational processes. There are more respondents among students with whom experimental, communicative and cognitive components prevail. The relational component prevails among future teachers. The future pupils' parents demonstrate a tendency for experimental and behavioral components of the readiness in question to be weakly distinct.

The ethnic worldview structure also differentiates among subjects of educational processes. Among the $11^{\text {th }}$ grade students there are more respondents with a tendency to a higher level of development of components such as ethnic position and inter-ethnic management. Respondents who are future teachers demonstrate a higher level of development of ethnic orientation. Parents demonstrate the ability to go beyond the ethnic frame.

The correlation of readiness for interaction with inoethnic subjects in educational processes with ethnic worldview is of a multifaceted character. At that, a multiethnic worldview is correlated with weak distinctness of certain components of readiness for interaction with inoethnic subjects in educational processes (behavioral, experimental, emotional, communicative and cognitive components), and, vice versa, a stronger distinctness of these components is correlated with the monoethnic worldview.

The further investigation of readiness for interaction with inoethnic subjects suggest that further work is needed with the instrumentation, the study sampling structure and a series of formative experiments.

\section{Limitations}

In the current study, the factor analysis of complex phenomena is actively applied. As is known, this type of statistical analysis is a research method allowing one to define the direction of further investigations by means of other methods. More to the point, the factor analysis results to a great extent are correlated with the researcher's personality and scientific thought. All of this imposes a certain restriction on the results of the study - they are to be considered to be a description of the reality under study at its first approximation. 


\section{References}

Arzamasceva, N. G. (2014). Razvitie etnicheskoy tolerantnosti studentov v processe obucheniya $\mathrm{v}$ vuze [Development of students' ethnic tolerance in the course of university education]. Sovremennye problemy nauki i obrazovaniya [Contemporary Issues in Science and Education], 1. Retrieved from http://www.science-education.ru/ru/article/view?id=12215.

Belinskaya, E. P., \& Stefanenko, T. G. (2000). Etnicheskaya socializaciya podrostka [Ethnic socialization of an adolescent]. Moscow: MPSI; Voronezh, Russia: NPO "MODEK".

Bondarevskaya, E. V., \& Kulnevich, S. V. (1999). Pedagogika: lichnost' v gumanisticheskih teoriyah $i$ sistemah vospitaniya [Pedagogy: Personality in humanistic theories and educational systems]. Rostov-na-Donu, Russia: Tvorcheskiy centr "Uchitel".

Dyachenko, M. I., \& Kandybovich, L. A. (1978). Psihologicheskie problemy gotovnosti k deyatel'nosti [Psychological issues in readiness to an activity]. Minsk: Izdatelstvo BGU.

Epshtein, M. N. (2001). Filosofija vozmozhnogo. Modal'nosti v myshlenii i kul'ture [Philosophy of the possible. Modalities in thinking and culture]. Saint Petersburg: Aletejja.

Federalnyy Professionalniy standart pedagoga [Federal Professional standard of an education specialist] (2013, February 15). Retrieved from http://минобрнауки.рф/документы/3071.

Fedorova, S. N. (2008). Sistemnyy podhod k etnokul'turologicheskoy podgotovke buduschih pedagogov: monografiya [Systemic approach to ethno-culturological preparation of future teachers]. Yoshkar-Ola, Russia: GOU VPO "Mariyskiy gosudarstvennyy universitet".

Grishina, N. V. (2008). Psihologija konflikta [Psychology of conflicts]. Saint Petersburg: Piter. (Original work published 2000)

Gukalenko, O. V. (2014). Polikulturnoe obrazovatel'noe prostranstvo kak factor social'no-pedagogicheskogo obespecheniya bezopasnosti detey i molodyozhi [Policultural education as a factor of socioeducational provision of safety for children and youths]. Cennosti i smysly [Values and Meanings], 4, 123-133.

Gurieva, S. D., \& Kinunen T. L. (2007) Metodika "Sozdaj planetu” [“Create your planet" method]. In Conference proceedings “Ananyevskie chtenija - 2007”. L.A. Tsvetkova (Ed.), (pp. 389391). Saint Petersburg: Saint Petersburg University Press.

Kalmykova, E. S., \& Mergentaler, E. (1998). Narrativ v psihoterapii: Rasskazy pacientov o lichnoy istorii (Chast' 1 , teoreticheskaya) [Narrative in psychotherapy: The patients' narratives of their personal history. (Part 1: Theoretical)]. Psihologicheskiy zhurnal [Psychological Journal], 5, 97-102.

Leontiev, D. A. (2007). Psihologiya smysla [Psychology of the meaning]. Moscow: Smysl. (Original work published 1999)

Pochebut, L. G. (2007). Vzaimoponimanie kul'tur [The cultures' mutual understanding]. Saint Petersburg: Saint Petersburg University Press.

Poshtareva, T. V. (2006). Teoriya i praktika formirovaniya etnokul'turnoy kompetentnosti uchaschihsya $\mathrm{v}$ polietnicheskoy obrazovatel'noy srede: monografiya [The theory and practice of development of ethnocultural competence in students in the polytechnical educational environment]. Stavropol, Russia: Litera.

Rubinshtein, S. L. (2012). Bytie i soznanie [Being and consciousness]. Saint Petersburg: Piter. (Original work published 1957)

Soldatova, G. U. (1998). Psihologiya mezhetnicheskoy napryazhennosti [Psychology of interethnic tensions]. Moscow: Smysl.

Stefanenko, T. G. (2014). Etnopsihologiya [Ethnopsychology]. Moscow: Aspekt-Press. (Original work published 1999)

Strekalova, N. B. (2015). Gotovnost' specialistov k deyatel'nosti v usloviyah informatizacii obschestva [The professionals' readiness to act under the conditions of informatization of the 
society]. Izvestiya Samarskoy gosudarstvennoy sel'sko-hozyaystvennoy akademii [Samara State Agricultural Academy Bulletin], 2, 116-119.

Uznadze, D. N. (2004). Obschaya psihologiya [General psychology]. Moscow: Smysl; Saint Petersburg : Piter. (Original work published 1940)

Valiev, R. A., \& Karimova, G. V. (2015). Struktura gotovnosti buduschih pedagogov k vzaimodejstviju s inoetnichnymi subyektami obrazovatelnogo prostranstva [The structure of readiness of future teachers to interact with the migrant subjects of educational space]. Izvestija Saratovskogo universiteta. Novaja serija. Akmeologija obrazovanija. Psihologija razvitija [Saratov University Bulletin. New series. Educational acmeology. Developmental psychology], 4(3), 244-247.

Valiev, R. A., Valieva, T. V., Vorobyeva, S. D., \& Smirnov, A. V. (2014). Etnicheskaya kartina mira municipal'nyh sluzhaschih Srednego Urala [Ethnic worldview in municipal officials of the Middle Urals]. Pedagogicheskoe obrazovanie v Rossii [Pedagogical Education in Russia], 5, 191-197.

Vasilyev, Yu. K. (1978). Voprosy formirovania gotovnosti k professional'noy deyatel'nosti: ekspressinformaciya [Issues in the development of readiness for professional activity: Brief information]. Moskva: Znanie.

Original manuscript received October 01, 2015

Revised manuscript accepted January 30, 2016

First published online March 30, 2016 